\title{
COVID-19 Tedavisi İçin Türkiye'de Belirlenen Hastanelerin Seçiminde Etkili Olan Kriterlerin Değerlendirilmesi
}

\author{
Kevser YURDAKUL ${ }^{1}$, Şeyda GÜR ${ }^{2}$, Tamer EREN ${ }^{1 *}$, Hacı Mehmet ALAKAŞ ${ }^{1}$ \\ ${ }^{1}$ Kırıkkale Üniversitesi, Endüstri Mühendisliği Bölümü, 71100, Kırıkkale, Türkiye. \\ ${ }^{2}$ Harran Üniversitesi, Organize Sanayi Bölgesi Meslek Yüksekokulu, 63200, Şanlıurfa, Türkiye \\ (ORCID: 0000-0002-8942-7187) (ORCID: 0000-0002-4639-9657) \\ (ORCID: 0000-0001-5282-3138) (ORCID: 0000-0002-9874-7588)
}

\begin{abstract}
$\ddot{O} z$
Aralık 2019 tarihinde Çin'de ortaya çıkan ve hızlı bir şekilde tüm dünyaya yayılarak gücünü ve etkisini gösteren COVID19 virüsü, WHO (World Health Organization) tarafindan pandemi olarak ilan edilmiştir. Dolayısıyla bu denli bulaşıcı ve ölümcül bir hastalığın tedavisinin, sağlıklı bireylere bulaştırmadan ve tüm insanların sağlı̆̆ını koruyacak bir şekilde, donanımlı sağlık kuruluşlarında yapılması büyük önem arz etmektedir. Yapılan bu çalışmada Türkiye'de vakaların görülmesi üzerine, Türkiye Cumhuriyeti Sağlık Bakanlığı tarafindan COVID-19 hastalarının tedavi edilmesi için belirlenen 25 referans hastanesinin seçiminde etkili olan kriterlerin değerlendirilmesi ve bu kriterlerin önem derecelerine göre sıralanması amaçlanmıştır. Değerlendirmede, belirlenen 25 referans hastaneye dair yedi kriter, COVID-19 virüsünün özellikleri ve yayınlanan rehberler ve raporlar incelenerek belirlenmiştir. Daha sonra kriterler, alanında uzman kişilerin görüşleri alınarak Çok Ölçütlü Karar Verme (ÇÖKV) yöntemlerinden Analitik Hiyerarşi Prosesi (AHP) ve Analitik Network Prosesi (ANP) yöntemleri ile kriterler karşılaştırılmış ve ağırlıklandırılmıştır. Yapılan çalışma neticesinde, her iki yöntemde de benzer sonuçlar elde edilmiş ve en önemli üç kritere bakıldığında salgın ile mücadelede sağlık kuruluşlarının hem teknik hem de personel bakımından donanımının bu süreçte oldukça önemli olduğu sonucuna ulaşılmıştır. Bu sonuçlardan hareketle, ANP yöntemiyle kriterler arasında içsel ve dışsal bağımlılıkların olduğu düşünüldüğünde de AHP yöntemi ile benzer sonuçlar elde edildiği gözlemlenmiştir.
\end{abstract}

Anahtar kelimeler: COVID-19, koronavirus, çok ölçütlü karar verme, analitik hiyerarşi prosesi, analitik network prosesi, hastane seçimi.

\section{Evaluation of The Criteria That Affect the Selection of Hospitals in Turkey for Covid-19 Treatment}

\begin{abstract}
The COVID-19 virus, which emerged in China in December 2019 and rapidly spread all over the world, was declared as a pandemic by WHO (World Health Organization). Therefore, it gains more importance that such an infectious and fatal disease is treated in well-equipped health institutions without infecting healthy individuals and in a way that protects the health of all people. In this study, it was aimed to evaluate the criteria that are effective in the selection of 25 reference hospitals determined by the Ministry of Health of the Republic of Turkey for the treatment of COVID-19 patients after the cases were seen in Turkey and to rank these criteria according to their degree of importance. seven criteria of the 25 reference hospitals were determined by examining the characteristics of the COVID-19 virus and published guidelines and reports. Then, the criteria were compared and weighted with the Analytical Hierarchy Process (AHP) and Analytical Network Process (ANP) methods, which are the Multi Criteria Decision Making (MCDV) methods, by taking the opinions of the experts in the field. As a result of the study, similar results were obtained in both methods and when the three most important criteria were considered, it was concluded that the equipment of the health institutions in terms of both technical and personnel was very important to fight against the pandemic in this process. By depending on the results, it was observed that similar results were obtained with the AHP method, given that there are internal and external dependencies between the criteria with the ANP method.
\end{abstract}

Keywords: COVID-19, coronavirus, multi-criteria decision making, analytical hierarchy process, analytical network process, hospital selection.

*Sorumlu yazar: tamereren@gmail.com

Geliş Tarihi: 23.02.2021, Kabul Tarihi: 29.04.2021 


\section{Giriş}

Tarih boyunca insanlar, bulaşıcı hastalıkların neden olduğu birçok salgın ile karşı karşıya kalmıştır. Veba salgını, Kanamalı Ateş, Kolera salgını, AIDS virüsü, ağır akut solunum yolu yetersizliği sendromu olarak bilinen SARS, Ebola ve Domuz Gribi gibi salgın hastalıklar dünya çapında birçok insanın ölümüne neden olmuştur [1]. Bu salgınların ardından Aralık 2019 tarihinde, Çin'in Hubei eyaletinin en büyük şehri olan Wuhan'da, Coronavirus $(\mathrm{CoV})$ tipi beta-CoV gurubundan, $\mathrm{CoV}$ ailesinin yedinci üyesi olarak COVID-19 salgını ortaya çıkmıştır [2, 3]. Bu salgının kaynağı halen araştırılırken, bazı sonuçlar COVID-19 salgınının, Wuhan şehrinde, vahşi hayvanların satıldığı deniz ürünleri pazarında ortaya çıktığını ve oradan insanlara bulaştığını göstermektedir [4].

Temel üreme sayısı veya temel bulaşıcılık katsayısı olarak bilinen $\mathrm{R}_{0}$ değeri, yani virüsü taşıyan her bireyin kendisinden başka ortalama kaç kişiye bulaştırabileceğini gösteren bu değer, COVID-19 salgını için $\mathrm{Wu}$ ve ark. [5] tarafından 2,47-2,86 olarak hesaplanmıştır. İlk tespit edilen vaka ile virüs, bu değer göz önüne alındığında insandan insana kolayca bulaşması nedeniyle önce Çin, ardından diğer ülkelere hızla yayılmıştır (Şekil 1) ve Mart 2020 itibariyle 116 ülkeye ek Türkiye'de dâhil olmak üzere, toplamda 117 ülkede COVID-19 vakasına rastlanmıştır. Bu ciddi yayılımı nedeniyle WHO (World Health Organization), COVID-19'u pandemi olarak ilan etmiştir [6].

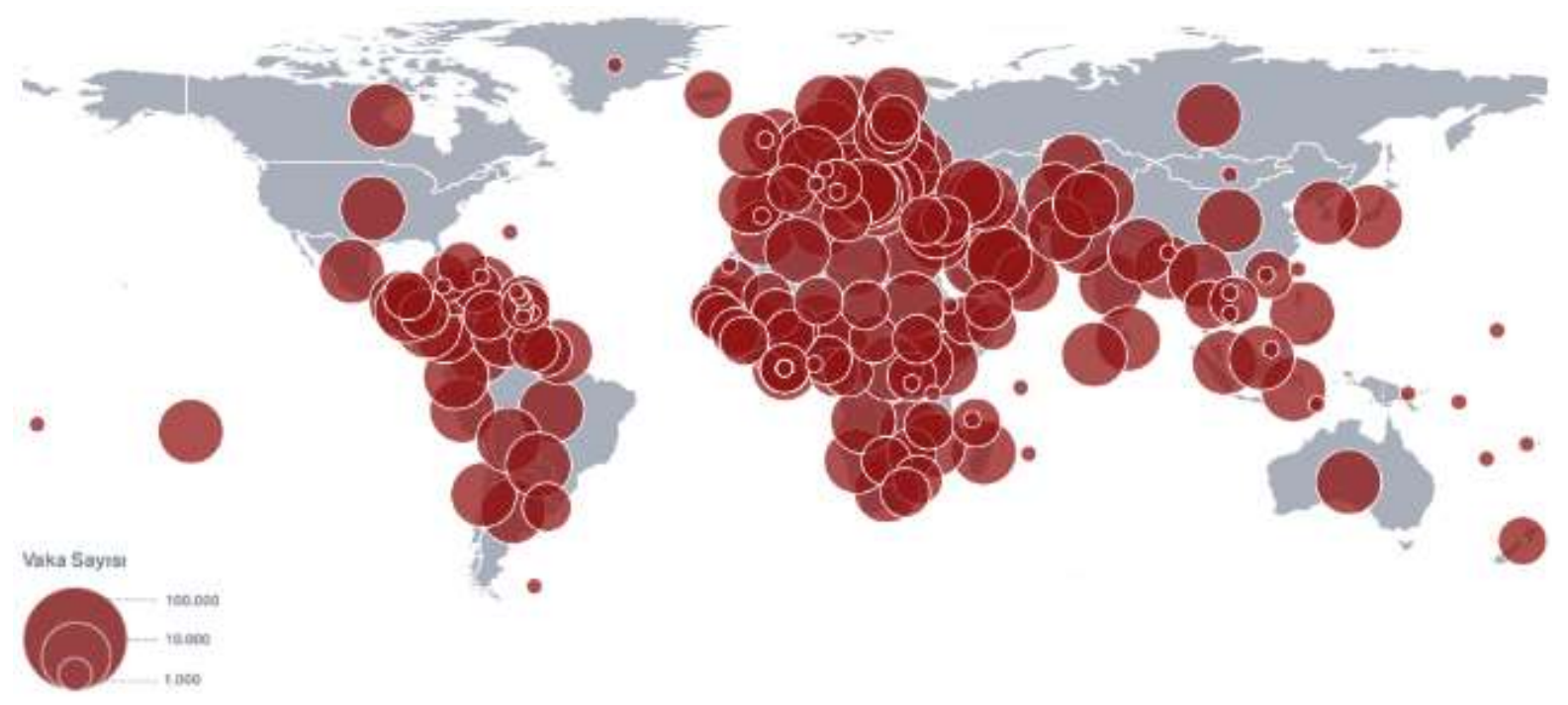

Şekil 1. Ülkelere Göre COVID-19 Vaka Sayısı (10 Kasım 2020 Tarihli Harita) [7]

WHO'nun 2020 Kasım verilerine göre Çin'de ortaya çıkan bu virüsten 200.000'nin üzerinde vefat ile en çok Amerika Birleşik Devletleri etkilenirken, Türkiye'de ise 10.000'nin üzerinde vefat olduğu açıklanmıştır [8].

Yapılan çalışmalar incelendiğinde, COVID-19 hastalığının başlıca belirtileri \%81,8 ateş, \%48,2 öksürük ve \%32,1 kas ağrıları ve yorgunluk olarak sıralanmaktadır [9]. Bu belirtilerin yanı sıra solunum yetmezliği, şiddetli zatürre, yüksek ateş gibi semptomları olan hastalar, yoğun bakımlarda uzman hekimler tarafından oksijen desteği sağlanarak tedavi edilmektedir [2]. WHO, bu tedavi sürecinde savunmasız sağlık tesislerine sahip yani, salgına karşı savaşacak donanımlı hastaneleri olamayan ülkelerin, büyük tehdit altında olabileceğini duyurmuştur [10]. Dolayısıyla bu süreçte, hastaların gerekli donanımlara sahip hastanelerde, sağlıklı bireylerden izole ve tüm insanların sağlı̆̆ını koruyacak bir şekilde tedavi edilmesi oldukça önemlidir. Türkiye'de COVID-19 vakalarının görülmesi üzerine, T.C. Sağlık Bakanlığı tarafından yurt genelinde hastaların tedavi edilebileceği 25 referans hastane belirlenmiştir. Daha sonra Türkiye'de vakaların artması nedeniyle Sağlık Bakanlığı tarafindan "Bünyesinde Enfeksiyon Hastalıkları ve Klinik Mikrobiyoloji, Göğüs hastalıkları, İç Hastalıkları uzmanı hekimlerden en az ikisinin bulunduğu ve 3. seviye erişkin yoğun bakım yatağı bulunan" tüm hastaneler pandemi hastanesi (salgınla mücadele eden) olarak ilan edilmiştir [11]. Hastanelerde doluluk oranlarının artmasıyla Çin'de büyük, geçici ve donanımlı Fangcang barınak hastaneleri kurulurken, 
Türkiye'de ise nüfusu oldukça fazla olan ve vakaların sıkça görüldüğü İstanbul'da, COVID-19 hastalarının tedavi edilmesi amacıyla 25 referans hastaneye ek olarak iki yeni ve kalıcı "çok amaçlı acil durum hastaneleri" inşa edilmiştir [12, 13].

Hastane seçimi, genel anlamda hastaların ihtiyaçlarına ve tercihlerine göre hastaneleri değerlendirerek karar verdikleri bir süreçtir. Bu süreçte, amaca en uygun kriterler ile hastanelerin değerlendirilmesi oldukça önemlidir. Literatürde birçok amaç doğrultusunda hastaların, hastane seçiminde etkili olan kriterler değerlendirilmiştir [14-16]. Şuanda içinde bulunulan salgın sürecinde, COVID-19 teşhisi konulan hastalar, özel hastaneler hariç belirlenen hastaneler dışında bir hastanede tedavi olma şansına sahip değildir. Dolayısıyla tedavi için gidilebilecek hastanelerin belirlenmesi, bu konuda uzman ve üst düzey karar vericiler tarafindan gerçekleştirilmektedir. Literatürde hastanelerin yer ve tedarikçi seçimi, hastanelerin hizmet kalitesinin ve performansının değerlendirilmesi ve hastanelerin afetlere karşı değerlendirilmesi gibi konularda çalışmaların bulunmasına rağmen salgın hastalıkların tedavi edilebileceği, hastanelerin seçimine özgü bir çalışmaya rastlanmamıştır [17-24]. Bu nedenle yapılan çalışmada, Türkiye'de hastalığın ilk görüldüğü, önemli kararların verildiği günlerde, COVID-19 hastalarının tedavisi için belirlenen 25 referans hastanesinin seçim kararında etkili olan tüm kriterlerin değerlendirilmesi ve önem derecelerinin belirlenmesi amaçlanmıştır. $\mathrm{Bu}$ amaçlar doğrultusunda literatürde bulunan çok sayıda yöntem içerisinden belirli bir aralıkta tutarsızlığa izin vermesinden dolayı AHP, kriterleri gruplandırarak bağımlılıkları dikkate almasından dolayı ANP yöntemleri kullanılmış ve sonuçlar karşılaştırılmıştır.

$\mathrm{Bu}$ çalışma beş ana bölümden oluşmaktadır. Birinci bölüm giriş bölümü olup, ikinci bölümde çalışmada kullanılan ÇÖKV yöntemlerinden AHP ve ANP yöntemlerine dair bilgiler yer almaktadır. Üçüncü bölümde yapılan uygulama tüm adımlarıyla anlatılmıştır. Dördüncü bölümde uygulama sonuçları karşılaştırılmış ve değerlendirilmiştir. Son bölüm olan beşinci bölümde ise elde edilen sonuçlar genel olarak değerlendirilmiş ve ileride yapılacak çalışmalar için önerilerde bulunulmuştur.

\section{Materyal ve Metot}

Karar verme süreci iş hayatında ya da günlük hayatta her gün her an yaşanılan bir süreçtir. Kişiler bulundukları mevcut durumlar içerisinde karar verirken, aslında farkında olmadan kararının avantajlarını ve dezavantajlarını dikkate alarak bir seçim yapmaktadırlar. Stratejik kararlar alınırken de birçok kriter göz önüne alınması ve bilimsel yöntemlerin kullanılması büyük önem taşımaktadır. $\mathrm{Bu}$ çalışmada da kriterlerin ağırlıklandırılması ve farklı yöntemler ile sonuçların karşılaştırılması için AHP ve ANP yöntemleri kullanılmıştır.

\subsection{Analitik Hiyerarşi Prosesi Yöntemi}

AHP, Saaty tarafından geliştirilmiş, karmaşık, çok kriterli karar problemlerinin çözümü için kullanılan bir yöntemdir [25]. AHP çift yönlü karş1laştırmalar yapan bir ölçüm teorisidir ve öncelikler elde etmek için uzmanların kararına dayanmaktadır [26]. Enerji, gıda, ulaştırma ve lojistik, eğitim, tekstil, sağlık vb. alanlarda sıç̧a tercih edilen bir yöntemdir [27-33]. Özellikle sağlık alanına bakıldığında diğer ÇÖKV yöntemlerine oranla, AHP yönteminin \%56 oranla tercih edildiği görülmüştür [34]. Kullanım kolaylığı, genişletilebilir olması, hiyerarşik yapısının kolayca büyük boyutlu problemlere uyacak şekilde ayarlanabilir olması, yoğun veri içermemesi ve karar verici için kabul edilebilir bir tolerans aralığında tutarsızlığa izin veren tek yöntem olması avantajları nedeniyle AHP yöntemi, bu çalışmada hastane seçimindeki kriterlerin değerlendirilmesi amacıyla tercih edilmiştir [35, 36]. Bu yöntem kriterlerin önem derecelerinin belirlenmesinin yanı sıra, alternatifleri de sıralayarak, aralarından en uygun seçimi yapmayı amaçlamaktadır. Çalı̧̧ma kapsamında, AHP yöntemi kriter ağırlıklandırması için kullanıldığından, alternatiflerin değerlendirilmesi kısmına yer verilmemiştir. AHP yöntemi Şekil 2'de gösterildiği gibi 4 aşamadan meydana gelmektedir. 


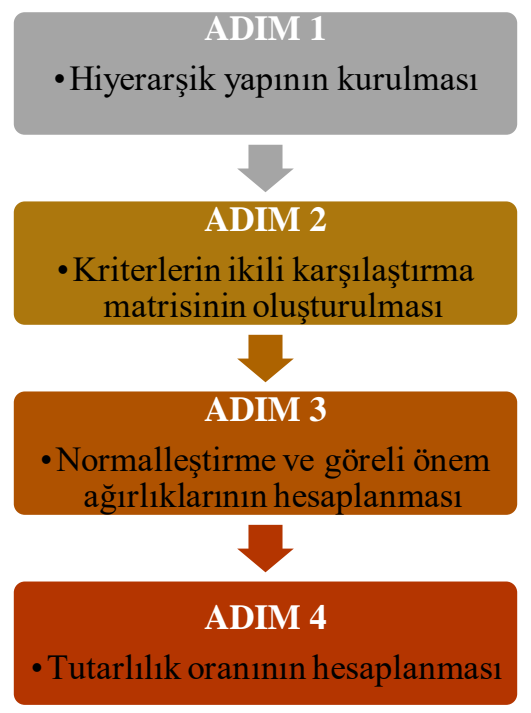

Şekil 2. AHP Yöntemi Aşamaları

Adım 1: AHP yönteminde, öncelikle problemin çerçevesi oluşturulmaktadır ve daha sonra hedef belirlenmektedir. Belirlenen hedef başta olmak suretiyle, hedefe bağlı olarak kriterler ve kriterlere bağlı alternatifler hiyerarşik düzende gösterilmektedir. Uygulamada ise sadece kriterler değerlendirileceğinden dolayı ağ yapısı, belirlenen hedefi ve literatür kapsamında oluşturulan kriterleri içermektedir.

Adım 2: Hiyerarşik yapının oluşturulmasının ardından konuda uzman kişi/kişiler tarafından kriterler arasında ikili karşılaştırma matrisi oluşturulmaktadır. Bu matrisin oluşturulması için Tablo 1'de verilen Saaty'nin 1-9 önem skalası kullanılmaktadır. Uygulamada bu adımda alanında uzman üç karar verici, ayrı ayrı hazırlanmış anketleri 1-9 skalasına göre doldurarak kriterleri karşılaştırarak ikili karşılaştırma matrislerini oluşturmaktadır.

Tablo 1. Önem Skalası

\begin{tabular}{cc}
\hline Önem Derecesi & Tanım \\
\hline 1 & Eşit önemli \\
3 & Biraz daha önemli \\
5 & Çok daha önemli \\
7 & Aşırı önemli \\
9 & Kesinlikle daha önemli \\
$2,4,6,8$ & Ara değerler \\
\hline
\end{tabular}

Adım 3: Yöntemin bu adımında bir önceki adımda elde edilen ikili karşılaştırma matrisindeki her bir kriterin eşit değerlendirilmesi için normalizasyon işlemi eşitlik (1) yardımıyla yapılmaktadır. Normalizasyon işlemi gerçekleştirildikten sonra, her bir kriterin ağırlığı eşitlik (2) ile hesaplanmaktadır. Uygulamada ise uzmanlarca oluşturulan üç farklı ikili karşılaştırma matrisi için ayrı ayrı normalizasyon işlemi gerçekleştirilerek kriter ağırlıkları belirlenmektedir.

$$
\begin{gathered}
b_{i j}=\frac{a_{i j}}{\sum_{i=1}^{n} a_{i j}} \\
w_{i}=\frac{\sum_{i=1}^{n} b_{i j}}{n}
\end{gathered}
$$

Adım 4: Son adımda, kriter ağırlıklarını bulmak için oluşturulan karşılaştırma matrisinde yapılan karşılaştırmaların, tutarlı olup olmadığını değerlendirmek amacıyla Tutarlılık Oranı (TO) hesaplanmaktadır. TO hesaplanması için ikili karşılaştırma matrisinin en büyük özvektörü, $\lambda$ max eşitlik (3) ve (4) kullanılarak hesaplanmaktadır. 


$$
\begin{aligned}
& {\left[a_{i j}\right]_{n * n} *[w]_{n * 1}=\left[d_{i}\right]_{n * 1}} \\
& \lambda_{\max }=\max \left\{\sum_{i=1}^{n} \frac{d_{i}}{w_{i}}\right\}
\end{aligned}
$$

TO, eşitlik (5)'teki gibi Tutarlılık İndeksinin (Tí) rassal indekse oranıdır ve Tİ hesaplamak için eşitlik (6) kullanılmaktadır. Uygulamada her bir karar vericinin değerlendirmesindeki TO, Tablo 4'deki gibi hesaplanmıştır. Ancak her birinin ayrı değerlendirilmesi yerine, üç karar vericinin karşılaştırma matrislerinin geometrik ortalaması alınarak, ortak değerler edilir ve Adım 3 ve 4 ortak matris üzerinden tekrar edilir. Sonuç olarak ortak değer dikkate alınır.

$$
\begin{aligned}
& T O=\frac{T \dot{\mathrm{I}}}{R \dot{\mathrm{I}}} \\
& T \dot{\mathrm{I}}=\frac{\lambda_{\text {max }}-n}{n-1}
\end{aligned}
$$

Hesaplamalar neticesinde TO değerinin 0,10'un altında bulunması, elde edilen kriter ağırlıklarının tutarlı olduğu, aksi halde tutarsızlık oluştuğu ve ikili karşılaştırma matrisinin revize edilmesi gerektiği anlamına gelmektedir [33].

\subsection{Analitik Network Prosesi Yöntemi}

Saaty tarafindan geliştirilen ANP, AHP yönteminin genel biçimidir ve kriterleri, alternatifleri ve ayrıca bunlar arasındaki ilişkileri temsil eden bir ağ modelidir [37, 38]. Bağımlılığa izin vermesinin yanında bağımsızlığı da içermesi, gruplara veya öge kümelerine öncelik verme yeteneği olması gibi avantajları ile ANP yaygın olarak kullanılan ÇÖKV yöntemlerinden birisidir [27]. Ayrıca sağlık alanındaki ÇÖKV problemlerinde AHP yönteminden sonra en çok tercih edilen yöntemdir [34]. Yapılan çalışmada hastanelerin seçiminde etkili tüm kriterler tek başına oldukça önemli olsa da birbirleri ile etkileşim içerisinde olması sebebiyle ANP yöntemi bu etkileşimleri dikkate alarak probleme çözüm üretmede ve AHP yöntemi ile sonuçların karşılaştırılarak bu etkileşimlerin değerlendirilmesine olanak sağlayacaktır. ANP yöntemi Şekil 3'deki gibi 5 adımdan oluşmaktadır.

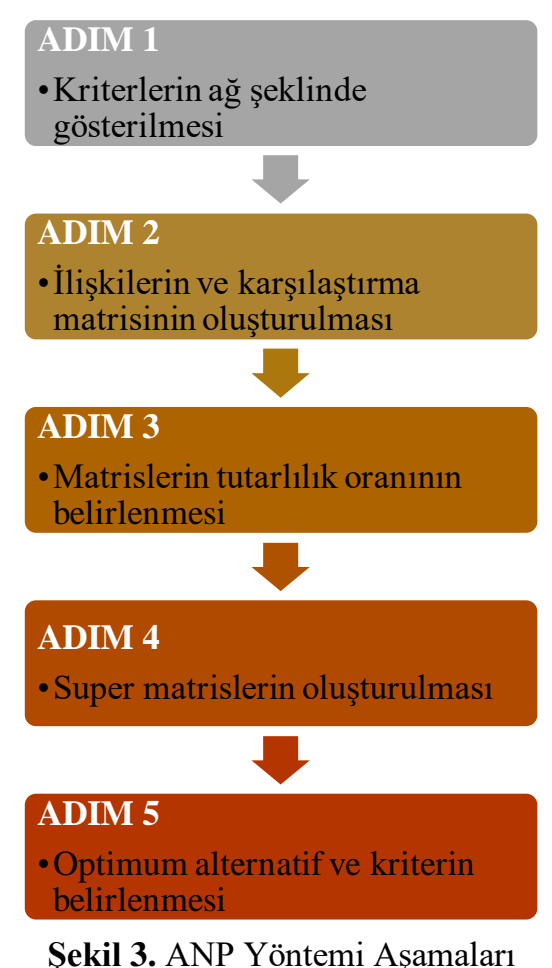

Adım 1: Öncelikle karar probleminin tüm çerçevesi ana kriterler, alt kriterler ve alternatifler ile belirlenmektedir ve rasyonel olarak bir ağ yapısına dönüştürülmektedir. Problemimizde alternatifler bulunmadığından Tablo 6'daki gibi ana ve alt kriterler oluşturulmuştur. 
Adım 2: Birbiri ile ilişkili kriterler bir arada olacak şekilde, tüm kriterler arasındaki etkileşimler dikkate alınarak bir ağ yapısı elde edilmektedir. Ardından belirlenen tüm kriterler, problem konusunda uzman kişiler ile değerlendirilmektedir. Değerlendirme yapılırken, Tablo 1'de verilen Saaty tarafından önerilen 1-9 skalası kullanılmaktadır. $\mathrm{Bu}$ aşamada faktörlerin birbirlerine göre üstünlükleri belirlenmektedir. Uygulamada ise oluşturulan ağ yapısında, ana kriterler içerisinde bulunan alt kriterler Super Decision paket programında ilişkilendirilerek karşılaştırma matrisleri oluşturulmuştur ve sonraki adımlar paket program tarafindan yapılmıştır.

Adım 3: İkili karşılaştırma matrislerinin oluşturulmasının ardından kriterlerin ve alternatiflerin öz vektörleri (ağırlıkları) hesaplanmaktadır. Daha sonra elde edilen bu ağırlıkların tutarlılığı değerlendirmek için tutarlılık oranı hesabı yapılmaktadır ve bu değerin 0,10 'dan küçük olması beklenmektedir.

Adım 4: Süper matris yapısında kriterler arasındaki ilişkiler gösterilmektedir. Bu matris önceliklerin elde edilmesinde karşılaştırma matrisi kullanılarak elde edilmektedir. Daha sonra ağırlıklandırılmış değerler ile sürper matrisdeki değerler çarpılarak ağırlıklandırılmış süper matris elde edilir ve bu matrisin $(2 \mathrm{n}+1)$ kuvveti alınır.

Adım 5: Yapılan işlemler sonunda elde edilen limit matrisi ile kriterlere ve alternatiflere ait önem dereceleri belirlenmektedir. En yüksek değere sahip kriter en önemli kriter, en yüksek değere sahip olan alternatif ise en iyi alternatif olmaktadır [39].

\section{Bulgular ve Tartışma}

Dünya geliştikçe sağlık sistemleri ve sağlık alanındaki teknolojilerde gelişmektedir. Bu gelişmeler ile birlikte, sağlık harcamaları da artmakta ve büyük bütçelere ihtiyaç duyulmaktadır. T.C. Cumhurbaşkanlığı Strateji ve Bütçe Başkanlığı 2020 Yılı Bütçesi Vatandaşın Bütçe Rehberi’ne göre sağlık sektörü, 2020 yılı bütçesinde \%17,2 ile en yüksek paya sahiptir [40]. İçinde bulunulan COVID19 salgını gibi kriz dönemlerinde, ülkeler bu kaynaklarını daha etkin ve verimli kullanmak durumunda kalmaktadır. Bu bağlamda, bu kriz döneminde alınacak her karar kritik önem taşımaktadır.

Acil durumlarda hastalık tanısı için hastane seçimi oldukça önemlidir [15]. Dolayısıyla bir hastalığın teşhis ve tedavi sürecinde hastanenin bütün kriterlerinin değerlendirilerek seçim yapılması da büyük önem arz etmektedir.

\subsection{Problemin Tanımlanması}

Bu çalışmada 2020 Mart ayında Türkiye'ye ivedi bir şekilde giriş yapan ve bugün halen dünyada birçok insanın hayatına mal olan COVID-19 virüsü nedeniyle hastalanan bireylerin tedavisinde hizmet verecek, referans hastaneler olarak belirlenen (Tablo 2 ve Şekil 4) 25 hastanenin seçiminde etkili olan kriterlerin değerlendirilmesi problemi ele alınmıştır. Problem sonuçlarının nasıl olacağı henüz bilinmeyen salgın sürecinin başlangıcını kapsamaktadır. Dolayısıyla böylesi belirsiz bir süreçte verilecek ilk kararlar en doğru şekilde ve tüm kriterler değerlendirilerek verilmelidir.

Türkiye'de yapılan bu çalışma ile belirlenen referans hastanelerin seçimindeki kriterlerin belirlenmesi ve bu kriterlerin ilişkileri de dikkate alınarak önem derecelerinin (ağırlıklarının) hesaplanması amaçlanmaktadır. Bu amaçlar doğrultusunda AHP ve ANP yöntemleri uygulanmış ve iki yöntemden elde edilen sonuçlar karşılaştırılmıştır. Uygulamada izlenecek adımlar Şekil 5 'te verilmiştir.

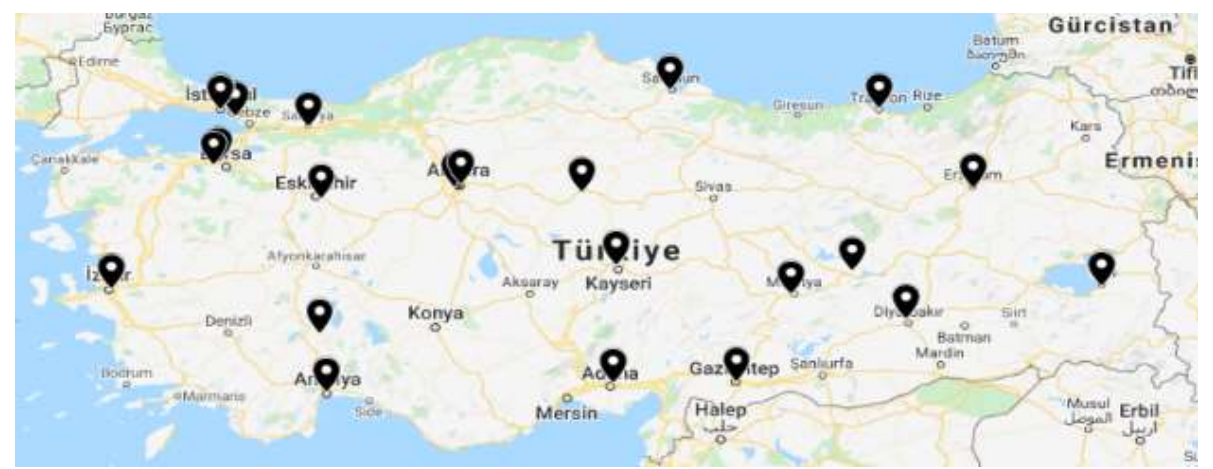

Şekil 4. Türkiye’de COVID-19 Tedavisi İçin Belirlenen 25 Referans Hasta 
Tablo 2. Türkiye'de COVID-19 Tedavisi İçin Belirlenen 25 Referans Hastane ve Bulundukları Bölgeler [41]

\begin{tabular}{lll}
\hline No & Hastane Adı & Ait Olduğu Bölge \\
\hline 1 & Adana Şehir Hastanesi & Adana Bölgesi \\
2 & Ankara Şehir Hastanesi & Ankara 2 (Bilkent) Bölgesi \\
3 & Ankara Eğitim ve Araştırma Hastanesi & Ankara 1 (Etlik) Bölgesi \\
4 & Antalya Eğitim ve Araştırma Hastanesi & Antalya Bölgesi \\
5 & Bursa Şehir Hastanesi & Bursa Bölgesi \\
6 & Bursa Yüksek İhtisas Eğitim ve Araştırma Hastanesi & Bursa Bölgesi \\
7 & Diyarbakır Gazi Yaşargil Eğitim ve Araştırma Hastanesi & Diyarbakır Bölgesi \\
8 & Elazı̆̆ Fethi Sekin Şehir Hastanesi & Elazı̆̆ Malatya Bölgesi \\
9 & Erzurum Bölge Eğitim ve Araştırma Hastanesi & Erzurum Bölgesi \\
10 & Eskişehir Şehir Hastanesi & Eskişehir Bölgesi \\
11 & Gaziantep Dr. Ersin Arslan Eğitim ve Araştırma Hastanesi & Gaziantep Bölgesi \\
12 & Isparta Şehir Hastanesi & Antalya Bölgesi \\
13 & Kartal Dr. Lütfe Kırdar Eğitim ve Araştırma Hastanesi & İstanbul Anadolu-Güney \\
14 & İstanbul Haseki Eğitim ve Araştırma Hastanesi & Bölgesi \\
15 & Bakırköy Dr. Sadi Konuk Eğitim ve Araştırma Hastanesi & İstanbul Fatih Bölgesi \\
16 & İstanbul Eğitim ve Araştırma Hastanesi & İstanbul Bakırköy Bölgesi \\
17 & İzmir Tepecik Eğitim ve Araştırma Hastanesi & İstanbul Fatih Bölgesi \\
18 & İzmir Dr. Suat Ceren Göğüs Hastalıkları ve Cerrahisi Ĕ̆itim ve Araştırma & İzmir Güney Bölgesi \\
19 & Kastanesi & İzmir Güney Bölgesi \\
20 & Malatya Eğitim ve Araştırma Hastanesi & Kayseri Bölgesi \\
21 & Sakarya Üniversitesi Eğitim ve Araştırma Hastanesi & Elazı̆galatya Bölgesi \\
22 & Samsun Eğitim ve Araştırma Hastanesi & Kocaeli Bölgesi \\
23 & Trabzon Kanuni Eğitim ve Araştırma Hastanesi & Samsun Bölgesi \\
24 & Van Eğitim ve Araştırma Hastanesi & Trabzon Bölgesi \\
25 & Yozgat Şehir Hastanesi & Van Bölgesi \\
\hline & & Ankara 1 (Etlik) Bölgesi \\
\hline
\end{tabular}

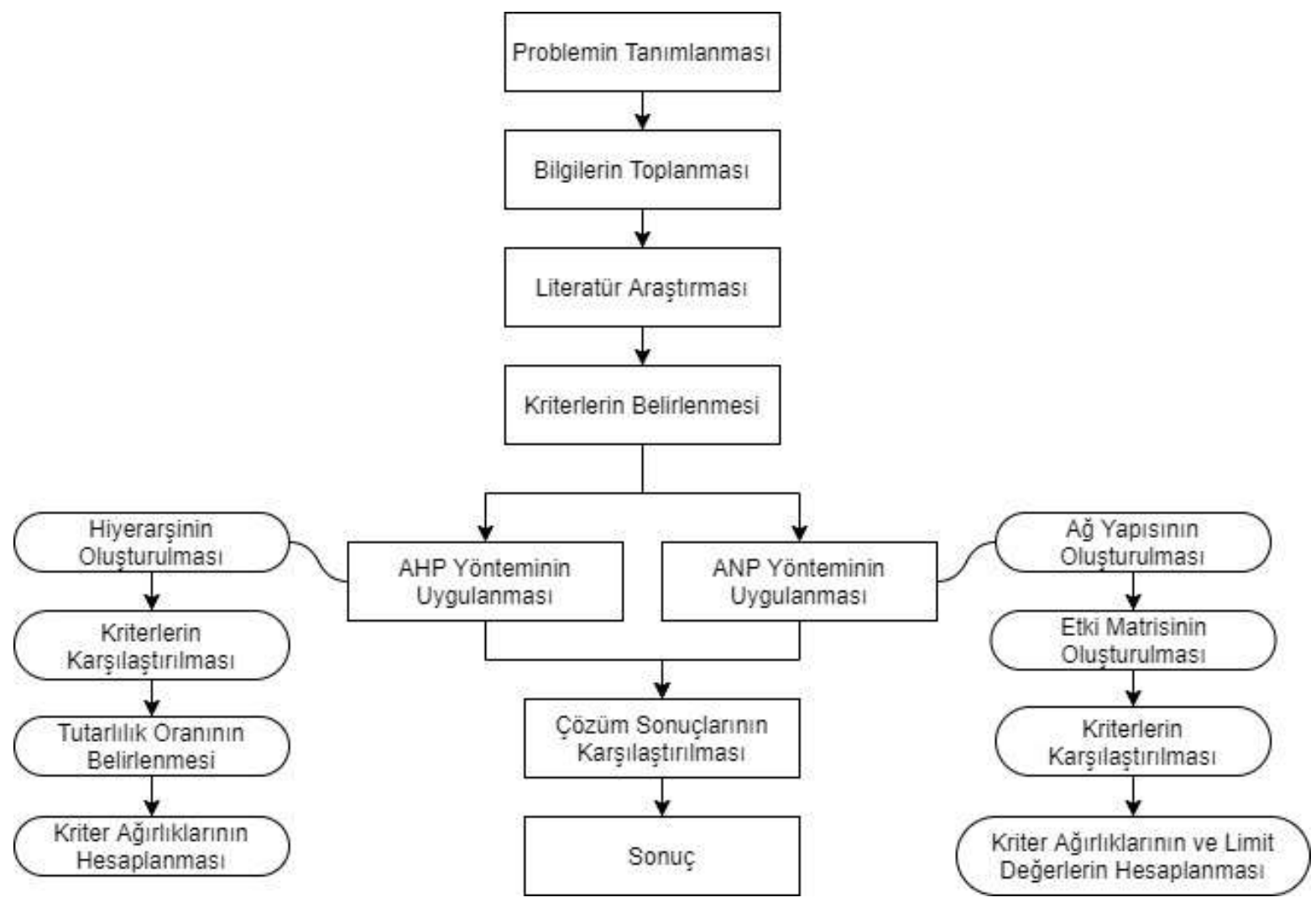

Şekil 5. Uygulama Adımlar 


\subsection{Problemin AHP Yöntemi ile Çözümü}

COVID-19 tedavisi için belirlenen 25 referans hastanenin değerlendirmesinde kullanılacak kriterler, T.C. Sağlık Bakanlığı Halk Sağlığı Genel Müdürlüğü ve T.C. Sağlık Bakanlığı Sağlık Hizmetleri Genel Müdürlük'leri tarafından yayınlanan rehberler ve genelgeler, COVID-19 salgın hastalı̆ğınn özellikleri ve belirlenen 25 hastanenin özelliklerinin incelenmesi doğrultusunda oluşturulmuştur ve Tablo 3'de verilmiştir.

Kriterler incelendiğinde K3 kriteri, K1 ve K6 kriterleri ile baz1 noktalarda birbirine benzemektedir. Ancak K1 ve K3 kriteri incelendiğinde, AI ve AI_Dal gruplarında olan hastaneler, eğitim araştırma hastanesi olma şartı taşırken AII grubu hastaneler, eğitim araştırma hastanesi olma şartı taşımamaktadır. Ayrıca bazı AI ve AI_Dal grubunda bulunan, eğitim kadroları henüz tamamlanamamış eğitim ve araştırma hastaneleri, eğitim kadroları tamamlanıp fiili olarak eğitim fonksiyonu kazanana kadar AII grubu hastaneler statüsünde değerlendirilmektedir. K3 ve K6 kriterine bakıldığında ise bir istisnai durum olarak Sakarya Eğitim Araştırma Hastanesi, AI grubunda bulunmasına karşı 1. Seviye yoğun bakıma sahip bir hastanedir [42]. Bu nedenle değerlendirme yapılırken bu istisnai durumlar, kriterler arasındaki farklılıkları ortaya koymaktadır.

Tablo 3. Kriterlerin Açıklaması

\begin{tabular}{|c|c|c|}
\hline Kriter Adı & Açıklama & Kaynak \\
\hline $\mathrm{K} 1$ & $\begin{array}{l}\text { E.A.H.(Eğitim Araştırma Hastanesi) } \\
\text { olması }\end{array}$ & $\begin{array}{l}\text { T.C. Sağlık Bakanlığı Halk Sağlığı } \\
\text { Genel Müdürlüğü[41] }\end{array}$ \\
\hline $\mathrm{K} 2$ & $\begin{array}{l}\text { Kurum türünün "G.H.(Genel hastane)" } \\
\text { veya "G.H.H.( Göğüs Hastalıkları ve } \\
\text { Göğüs Kalp Damar ve Cerrahisi } \\
\text { Hastaneleri)" olması }\end{array}$ & $\begin{array}{l}\text { T.C. Sağlık Bakanlığı Halk Sağlığı } \\
\text { Genel Müdürlüğü[41] }\end{array}$ \\
\hline K3 & $\begin{array}{l}\text { Hastanelerin rollerinin gruplaması (AI, } \\
\text { AI_Dal, AII grubu vb.) }\end{array}$ & $\begin{array}{l}\text { T.C. Sağlık Bakanlığı Halk Sağlığı } \\
\text { Genel Müdürlüğ̈̈[41] }\end{array}$ \\
\hline K4 & $\begin{array}{l}\text { Negatif basıçlı izolasyon sistemine } \\
\text { sahip bir hastane olması }\end{array}$ & Sözcü Gazetesi[43] \\
\hline K5 & Hastaneye erişim kolaylığının olması & - \\
\hline K6 & $\begin{array}{l}\text { 3. seviye erişkin yoğun bakım yatağı } \\
\text { bulunan bir hastane olması } \\
\text { Bünyesinde Enfeksiyon Hastalıkları ve }\end{array}$ & $\begin{array}{l}\text { T.C. Sağlık Bakanlığı Sağlık } \\
\text { Hizmetleri Genel Müdürlüğü[42] }\end{array}$ \\
\hline K7 & $\begin{array}{l}\text { Klinik Mikrobiyoloji, Göğüs hastalıkları, } \\
\text { İç Hastalıkları uzmanı hekimlerden en az } \\
\text { ikisinin bulunduğu bir hastane olması }\end{array}$ & $\begin{array}{l}\text { T.C. Sağlık Bakanlığı Sağlık } \\
\text { Hizmetleri Genel Müdürlüğü[42] }\end{array}$ \\
\hline
\end{tabular}

Problemin tutarlı bir çözümünün yapılabilmesi için problem tanımının tüm ayrıntıları ile gösterilmesi ve bir öncelik hiyerarşisine göre oluşturulması gerekmektedir. Problemimiz için başta amaç ve altında kriterlerin tanımlanmasıyla problem çerçevesi oluşturulmuş ve AHP yönteminin ilk adımı olan hiyerarşik gösterim Şekil 6'da verilmiştir.

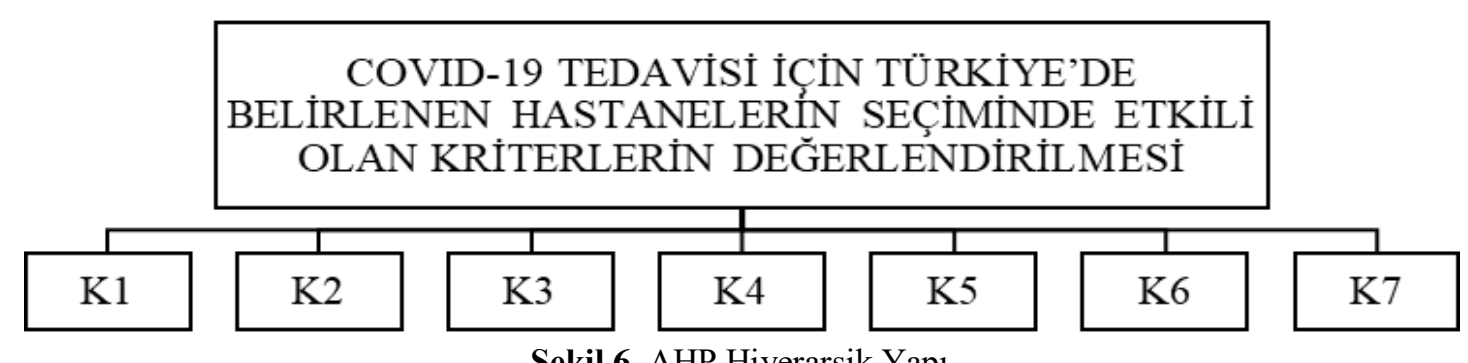

Şekil 6. AHP Hiyerarşik Yapı

COVID-19 tedavisi için belirlenen 25 hastanenin seçiminde etkili olan tüm kriterlerin belirlenmesiyle, bu kriterler sağlık alanında çalışan üç Karar Verici (KV) tarafından değerlendirilmiştir. KV1; bir eğitim ve araştırma hastanesinde COVID-19 yoğun bakımında çalışan hemşire, KV2; bir aile 
sağlığı merkezinde çalışan ebe-hemşire ve KV3; bir eğitim ve araştırma hastanesi çocuk hematoloji ve onkoloji kliniğinde çalışan klinik hemşire sorumludur.

Çok karar vericili süreçlerde her KV tüm kriterlerin karşılaştırılmasında yargıda bulunduğundan, bu yargıların uygun bir şekilde birleştirilmesi gerekmektedir. AHP ile grup kararları verilirken bireysel yargıların birleştirilmesinde, literatürde en çok geometrik ortalama yönteminin kullanıldığı görülmüştür [44-46]. Bunun sebebi karşılaştırma matrisinde simetrik elemanların birbirinin tersi olması gerekmesi ve bu koşulu geometrik ortalama yönteminin sağlamasıdır. Geometrik ortalama yönteminde bireysel yargıların birleştirilmesi (AIJ-Aggregation of Individual Judgements) ve bireysel önceliklerin birleştirilmesi (AIP-Aggregation of Individual Priorities) olarak iki yöntem bulunmaktadır. Ancak farklı birleştirmeler yapılmasına rağmen bu iki yöntemde aynı sonucu vermektedir [44].

Ele alınan problem için AIJ yöntemi kullanılarak her bir KV Tablo 1'de verilen Saaty'nin önem skalasını dikkate alarak, tüm kriterleri ikili olarak karşılaştırmıştır. Tablo 4'de tüm KV'lerin karşılaştırmalarının geometrik ortalamaları alınıp ortak değerler hesaplanmıştır. Ayrıca her bir KV'nin ve ortak karşılaştırma matrislerinin tutarlılık oranları da Tablo 4'de verilmiştir.

Ortak değerler ile oluşturulan karşılaştırma matrisi, tüm kriterlerin eşit değerlendirilebilmesi için normalize edildikten sonra kriterlerin ağırlıkları Tablo 5'de verilmiştir.

Tablo 4. COVID-19 Tedavisi İçin Belirlenen 25 Hastanenin Seçiminde Etkili Olan Kriterlerin Karşılaştırılması

\begin{tabular}{|c|c|c|c|c|c|c|}
\hline \multirow{2}{*}{ 1. Kriter } & \multicolumn{3}{|c|}{ Karar Verici } & \multirow{2}{*}{ 2. Kriter } & \multirow{2}{*}{$\begin{array}{l}\text { Geo. } \\
\text { Ort. }\end{array}$} & \multirow{2}{*}{$\begin{array}{l}\text { Ortak } \\
\text { Değer }\end{array}$} \\
\hline & KV1 & KV2 & KV3 & & & \\
\hline K1 & 3 & $1 / 4$ & 1 & K2 & 0,91 & 1 \\
\hline K1 & $1 / 2$ & $1 / 5$ & 1 & K3 & 0,46 & $1 / 2$ \\
\hline K1 & 7 & 3 & 5 & K4 & 4,72 & 5 \\
\hline K1 & 5 & $1 / 7$ & 5 & K5 & 1,53 & 2 \\
\hline K1 & $1 / 3$ & 1 & 1 & K6 & 0,69 & $1 / 2$ \\
\hline K1 & $1 / 4$ & $1 / 5$ & 1 & K7 & 0,37 & $1 / 3$ \\
\hline K2 & $1 / 3$ & 1 & 1 & K3 & 0,69 & $1 / 2$ \\
\hline K2 & 5 & 6 & 5 & K4 & 5,31 & 5 \\
\hline K2 & 3 & $1 / 4$ & 5 & K5 & 1,55 & 2 \\
\hline K2 & $1 / 5$ & 4 & 1 & K6 & 0,93 & 1 \\
\hline K2 & $1 / 5$ & 1 & 1 & K7 & 0,58 & $1 / 2$ \\
\hline K3 & 7 & 7 & 5 & K4 & 6,26 & 6 \\
\hline K3 & 5 & $1 / 4$ & 5 & K5 & 1,84 & 2 \\
\hline K3 & $1 / 2$ & 5 & 1 & K6 & 1,36 & 1 \\
\hline K3 & $1 / 3$ & 1 & 1 & K7 & 0,69 & $1 / 2$ \\
\hline K4 & $1 / 4$ & $1 / 9$ & 5 & K5 & 0,52 & $1 / 2$ \\
\hline K4 & $1 / 9$ & $1 / 3$ & $1 / 5$ & K6 & 0,19 & $1 / 5$ \\
\hline K4 & $1 / 9$ & $1 / 7$ & $1 / 5$ & K7 & 0,15 & $1 / 7$ \\
\hline K5 & $1 / 7$ & 7 & $1 / 9$ & K6 & 0,48 & $1 / 2$ \\
\hline K5 & $1 / 7$ & 1 & $1 / 5$ & K7 & 0,31 & $1 / 3$ \\
\hline K6 & $1 / 2$ & $1 / 5$ & $1 / 5$ & K7 & 0,27 & $1 / 4$ \\
\hline Tutarlılık Oranı & 0,09 & 0,08 & 0,07 & - & - & 0,03 \\
\hline
\end{tabular}

Tablo 5. AHP Kriter Ağırlıkları 


\begin{tabular}{cc}
\hline Kriterler & ĂğIrlklar \\
\hline K1 & 0,1161 \\
K2 & 0,1326 \\
K3 & 0,1830 \\
K4 & 0,0313 \\
K5 & 0,0742 \\
K6 & 0,1482 \\
K7 & 0,3146 \\
\hline
\end{tabular}

\subsection{Problemin ANP Yöntemi ile Çözümü}

COVID-19 sürecinde hastaların tedavi edilebilmesi için belirlenen 25 referans hastanenin seçiminde etkili kriterlerin değerlendirilmesi için, Tablo 3'de verilen kriterler ANP yönteminde alt kriterler olarak ele alınmıştır. Bununla birlikte alt kriterler rasyonel bir şekilde kategorize edilerek Tablo 6'da görüldügü gibi ana kriterler oluşturulmuştur.

Tablo 6. Kriterlerin Ana ve Alt Kriterlere Ayrılması

\begin{tabular}{|c|c|c|c|}
\hline Amaç & Ana Kriter & & Alt Kriter \\
\hline $\begin{array}{l}\text { COVID-19 } \\
\text { Tedavisi İçin } \\
\text { Belirlenen } 25 \\
\text { Hastanenin } \\
\text { Değerlendirilmesi }\end{array}$ & $\begin{array}{l}\text { Hastanenin } \\
\text { Konumu ve } \\
\text { Statüsü }\end{array}$ & $\begin{array}{l}\mathrm{K} 1 \\
\mathrm{~K} 2 \\
\mathrm{~K} 3 \\
\mathrm{~K} 5 \\
\mathrm{~K} 4 \\
\mathrm{~K} 6 \\
\mathrm{~K} 7\end{array}$ & $\begin{array}{l}\text { E.A.H. olması } \\
\text { Kurum türünün "G.H” veya "G.H.H.” olması } \\
\text { Hastanelerin rollerinin gruplamasında AI, AI_Dal veya AII grubu } \\
\text { bir hastane olması } \\
\text { Hastaneye erişim kolaylığının olması } \\
\text { Negatif basıçı izolasyon sistemine sahip bir hastane olması } \\
\text { 3. seviye erişkin yoğun bakım yatağı bulunan bir hastane olması } \\
\text { Bünyesinde Enfeksiyon Hastalıkları ve Klinik Mikrobiyoloji, } \\
\text { Göğüs hastalıkları, İç Hastalıkları uzmanı hekimlerden en az } \\
\text { ikisinin bulunduğu bir hastane olması }\end{array}$ \\
\hline
\end{tabular}

Toplamda 2 ana kriter ve yedi alt kriter, sağlık çalışanları ve yayınlanan genelgeler dikkate alınarak oluşturulmuştur. Ana kriterler incelendiğinde hastanenin konumu ve statüsü ana kriterinde hastanenin eğitim araştırma hastanesi, gögüs hastanesi, rol grupları ve hastaneye erişim kolaylığının bulunduğu görülmektedir. COVID-19 hastalığının bulaşıcı olması ve bir salgın hastalık olması sebebiyle hastanenin konumunun merkezi veya ücra bir yerde bulunması, dikkat edilmesi gereken bir konudur. Hastane donanımı ana kriteri incelendiğinde negatif basınçlı oda, 3. Seviye yoğun bakım ve belirli alanlarda uzman hekimlerin bulunması, hastalığın kolay yayılımı ve kimi zaman ağır tedavi süreçlerinden dolayı belirli donanımlara sahip hastanelerin büyük önem taşıdığını göstermektedir. Birbirini etkileyen bu kriterler arasındaki etkileşim Tablo 7'de ve ağ yapısı Şekil 7'de verilmiştir.

Tablo 7. ANP Etki Matrisi

\begin{tabular}{cccccccc}
\hline & K1 & K2 & K3 & K4 & K5 & K6 & K7 \\
\hline K1 & & & X & & X & X & X \\
K2 & & & X & & X & X & X \\
K3 & X & X & & & X & X & X \\
K4 & & & & & & X & \\
K5 & & & & & & & \\
K6 & X & X & X & X & & & \\
K7 & X & X & X & & X & & \\
\hline
\end{tabular}




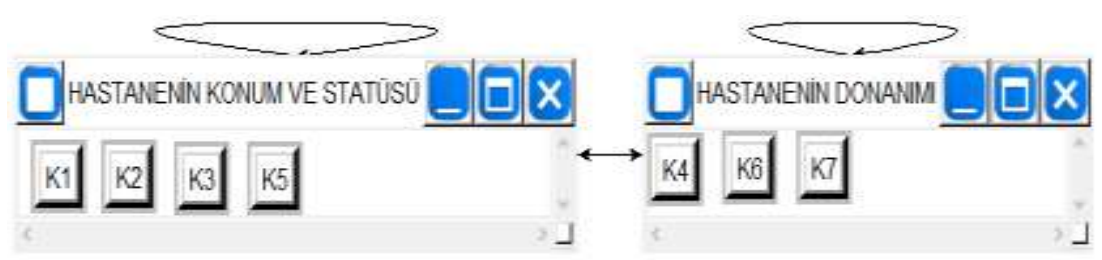

Şekil 7. ANP Super Decision Paket Programı Ağ Yapısı

Çalışmada ağ yapısı, kriterler arasındaki iç ve dış bağımlılıklar dikkate alınarak oluşturulmuştur. Örneğin, eğitim araştırma hastanesi olması kriteri (K1) ile hastane rollerinin gruplanması kriteri (K3) iç bağımlılı̆̆a sahipken, eğitim araştırma hastanesi olması kriteri (K1) ile belirli bölümlerden uzman hekimlerin bulunması kriteri (K7) dış bağımlılığı oluşturmaktadır.

COVID-19 tedavisi için belirlenen 25 hastanenin seçiminde etkili kriterlerin değerlendirilmesi problemi için, ağ yapısının oluşturulması ve sağlı çalışanları ile ikili karşılaştırmalarının oluşturulmasıyla elde edilen matrisler Super Decision paket programı yardımıyla çözülmüştür [47]. Çözüm sonucunda ulaşılan kriter ağırlıkları ve limit değerleri Tablo 8'de verilmiştir.

Tablo 8. ANP Kriter Ağırlıkları

\begin{tabular}{ccc}
\hline Kriterler & Ağırlıklar & Limit \\
\hline K1 & 0,2981 & 0,1792 \\
K2 & 0,1927 & 0,1159 \\
K3 & 0,4062 & 0,2442 \\
K4 & 0,1351 & 0,0619 \\
K5 & 0,1029 & 0,0539 \\
K6 & 0,3802 & 0,1516 \\
K7 & 0,4847 & 0,1933 \\
\hline
\end{tabular}

\section{4. Çözüm Sonuçlarının Karşılaştırılması}

COVID-19 tedavisi için belirlenen hastanelerin seçiminde etkili kriterlerin değerlendirilmesinde öncelikle etkili olan bir çok kriter, üç sağlık çalışanın görüşleriyle hiyerarşik düzene oturtularak, ikili gruplar halinde AHP yöntemi kullanılarak sıralanmıştır. Daha sonrasında tüm kriterler arasında etkileşim olabileceği düşünülerek, hiyerarşik düzeni içermeyen, ağ yapısı ile içsel ve dışsal bağımlılıkları dikkate alan ANP yöntemi kullanılarak tüm kriterler sıralanmıştır. Sonuç olarak elde edilen iki sıralama, Şekil 8'de verilen grafikte net bir biçimde ifade edilmiştir.

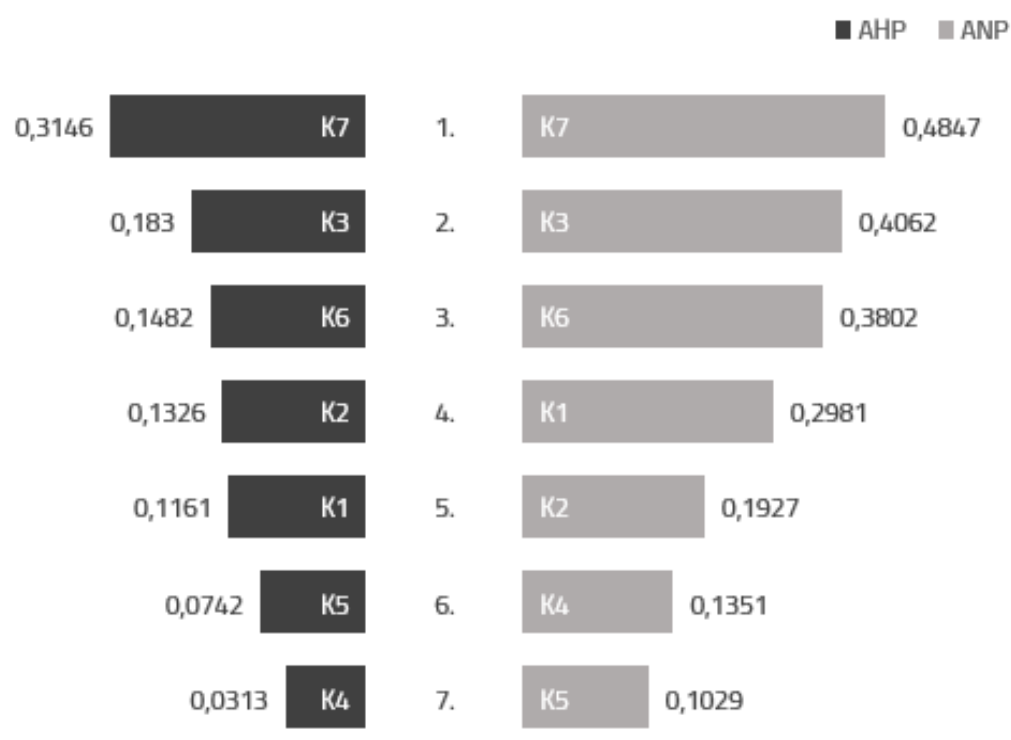

Şekil 8. Yöntemlere Göre Kriterlerin Öncelik Değerleri 
Türkiye'de COVID-19 salgının görülmesi üzerine salgının bulaş riski, sağlıklı bireylerin korunması ve hastaların iyi bir şekilde tedavi edilmesi için T. C. Sağlık Bakanlığı tarafından 25 referans hastane belirlenmiştir. COVID-19 tedavisi için belirlenen bu 25 hastanenin seçiminde etkili olan kriterler bu hastanelerin özellikleri, COVID-19 salgınının özellikleri ve bu süreçte yayınlanan rehberler incelenerek kriterler belirlenmiştir. Belirlenen yedi kriter ÇÖKV yöntemlerinden AHP ve ANP yöntemi ile değerlendirilmiştir.

İlk olarak AHP yöntemi sonucu incelendiğinde (Tablo 4'de) elde edilen sonucun kalitesini gösteren tutarlılık oranının, \%3 olarak hesaplandığı ve sonuçların tutarlı olduğu görülmüştür. Bununla birlikte elde edilen kriterlerin ağırlıklarının sıralamasına bakıldığında (Şekil 8), ilk sırada \%31 ile K7, ikinci sırada \%18 ile K3 ve üçüncü sırada ise K6 kriterinin yer aldığ görülmüştür ve sıralama K2, K1, K5, K4 olarak devam etmiştir. İkinci olarak kriterler arası bağımlılığı dikkate alan yapısı ve bununla birlikte kullanım alanı ve sonuçlarının güvenilirliği konusunda günlük hayata daha uygun olan ANP yönteminde elde edilen sonuçlar incelendiğinde (Şekil 8), ilk sırada \%48 ile K7, ikinci sırada \%41 ile $\mathrm{K} 3$ ve üçüncü sırada ise K6 yer aldığ 1 görülmüsstür ve sıralama K1, K2, K4, K5 olarak devam etmiştir. Elde edilen sonuçlara göre iki yöntemde de öncelik sıralaması \%80 oranında benzerlik göstermektedir. Dolayısıyla bu çalışmada, problemin yapısı kriterlerin birbirlerini etkilediği ve etkilemediği durumlarda aynı sonuçlar ile karşılaşıldığını göstermektedir.

\section{Sonuç ve Öneriler}

Aralık 2019 tarihi itibariyle Çin'de ortaya çıkan Coronavirus tipi COVID-19 salgın hastalı̆̆ı, bütün dünyaya yayılarak gücü ve etkisini göstermesiyle WHO tarafindan pandemi olarak ilan edilmiştir. Ateş, öksürük, solunum zorluğu gibi belirtileri ile COVID-19 virüsü insanların bağışıklık sistemlerine saldırarak, birçok insanın ölümüne neden olmaktadır. Solunum yolu ile insandan insana bulaşan bu virüse, Mart 2020 itibariyle Türkiye' de de rastlanmıştır. Bununla birlikte sayısı giderek artan vakalar ve vefatlar oluşmuştur. Vakaların artması ve bu virüsün çok kolay bir şekilde insandan insana geçmesi sebebiyle Türkiye'de, insan sağlığını korumak ve COVID-19 teşhisi konan hastaları iyileştirmek amacıyla birçok önlem ve karar alınmıştır. Alınan bu kararlar içerisinde, COVID-19 teşhisi konan hastaların hangi hastanelerde tedavi edileceği kararı, sağlıklı bireyleri korumak ve hasta bireyleri izole ederek iyileştirmek için oldukça önemlidir. Bu bağlamda Türkiye'de vakaların görülmesiyle T.C. Sağlık Bakanlığı tarafından, salgınla mücadelede ilk sırada tedavi sağlayacak, ülke genelinde 25 referans hastane belirlenmiştir.

Yapılan çalışmada COVID-19 tedavisi için belirlenen 25 hastanenin seçiminde etkili olan yedi kriter değerlendirilmiştir. Kriterler, seçilen 25 hastanenin özellikleri, COVID-19 virüsünün özellikleri ve bu süreçte yayınlanan rehberler incelenerek belirlenmiştir. Ele alınan bu kriterler ÇÖKV yöntemlerinden AHP ve ANP yöntemleri ile değerlendirilerek sıralanmıştır. Yapılan değerlendirmeler sonucunda, her iki yöntemde elde edilen öncelik sıralamasında, bünyesinde belirli alanlarda uzman hekimlerin bulunduğu bir hastane olması (K7), hastanelerin rollerinin gruplamasında AI, AI_Dal veya AII grubu bir hastane olması (K3) ve 3. seviye erişkin yoğun bakım yatağı bulunan bir hastane olmas1 (K6) kriterleri, en önemli ilk üç kriteri oluşturmaktadır. Suralamanın devamında ise kriterler iki yöntemde de birkaç farklılık dışında benzer şekilde sıralanmıştır. Bu sonuçlardan hareketle COVID-19 tedavisi için 25 referans hastanenin belirlenmesinde, uzman hekimlerin bulunduğu, tetkik ve tedavi konusunda donanımlı, yüksek seviye yoğun bakıma sahip hastanelerin seçildiği görülmüş ve hastanenin teknik ve personel olarak donanımının önemi bu sonuçlar ile vurgulanmıştır. Ayrıca kriterler arasındaki bağımlılıkları dikkate aldığından dolayı, ANP yönteminin güvenilir ve daha gerçekçi sonuçlar verdiği bilinmektedir [44, 48]. Bu çalışma da ANP yönteminde elde edilen sonuçlar, AHP yöntemi ile desteklenerek tutarlı sonuçlar elde edilmiştir.

$\mathrm{Bu}$ makalede ele alınan hastane seçimi süreci, tedavi sürecinin en iyi şekilde gerçekleştirilebilmesi için ilk ve önemli bir karar sürecidir. Özellikle salgınla mücadele sürecinde, bireyler arası bulaş riskinin azaltılması ve hastanın en iyi şekilde tedavi edilebilmesi adına bu kararın çok daha önemli hale geldiği görülmüştür. Bu bağlamda yapılan çalışma, hem hastane seçiminde etkili kriterlerin değerlendirilmesi hem de COVID-19 salgın hastalığını bir arada dikkate alınmasıyla literatüre katkı sağlamaktadır.

İleride yapılacak çalışmalarda belirlenen bu 25 hastaneye ek olarak, şuanda COVID-19 tedavisi için kullanılan bütün hastaneler dikkate alınarak belirlenen kriterlere, başka kriterlerde dahil edilerek 
değerlendirmeler yapılabilir. Tedavi veren hastanelerin sayısının artması ve hasta ve yakınlarına tercih imkânı doğması nedeniyle, hastaların hastane seçiminde etkili olan kriterler ve alternatifler incelenebilir. Ayrıca ÇÖKV yöntemlerinden diğer yöntemler de bu çalışma için kullanılabilir.

\section{Yazarların Katkısı}

Yurdakul K., veri hazırlama/analizi, yöntem uygulaması, makale yazımı-orijinal taslak hazırlama; Gür Ş., yöntem uygulaması, makale yazımı-orijinal taslak hazırlama; Eren T., makale yazma, inceleme ve düzenleme, makale kontrol; Alakaş H.M., makale yazma, inceleme ve düzenleme konularında katkıda bulunmuştur.

\section{Çıkar Çatışması Beyanı}

Yazarlar arasında herhangi bir çıkar çatışması bulunmamaktadır.

\section{Araştırma ve Yayın Etiği Beyanı}

Yapılan çalışmada araştırma ve yayın etiğine uyulmuştur.

\section{Kaynaklar}

[1] Zeren F., Hizarc1 A.E. 2020. The Impact of Covid-19 Coronavirus on Stock Markets: Evidence From Selected Countries. Muhasebe ve Finans İncelemeleri Dergisi, 3 (1): 78-84.

[2] Karcioğlu Ö. 2020. What is Coronaviruses, and How Can We Protect Ourselves. Anka Tip Dergisi, 2 (1): 66-71.

[3] Zhu N., Zhang D., Wang W., Li X., Yang B., Song J., ... \& Tan W. 2020. Coronavirus from Patients with Pneumonia in China. The New England Journal of Medicine, 382 (8): 727-733.

[4] Wang D., Hu B., Hu C., Zhu F., Liu X., Zhang J., ... \& Peng Z. 2020. Clinical Characteristics of 138 Hospitalized Patients With 2019 Novel Coronavirus-Infected Pneumonia in Wuhan, China. JAMA, 323 (11): 1061-1069.

[5] Wu J.T., Leung K., Leung G.M. 2020. Nowcasting and Forecasting the Potential Domestic and International Spread of the 2019-Ncov Outbreak Originating in Wuhan, China: A Modelling Study. The Lancet, 395 (10225): 689-697.

[6] WHO(World Health Organization), Coronavirus disease 2019 (COVID-19) Situation Report-52. https://www.who.int/docs/default-source/coronaviruse/situation-reports/20200312-sitrep-52covid-19.pdf?sfvrsn=e2bfc9c0_4 (Erişim Tarihi: 15.10.2020).

[7] Johns Hopkins Üniversitesi, COVID-19 Dashboard by the Center for Systems Science and Engineering (CSSE). https://coronavirus.jhu.edu/map.html (Erişim Tarihi: 10.11.2020).

[8] WHO(World Health Organization), Coronavirus Disease (COVID-19) Dashboard. https://covid19. who.int/table (Erişim Tarihi: 15.10.2020).

[9] Liu K., Fang Y.Y., Deng Y., Liu W., Wang M.F., Ma J.P., ... \& Liu H.G. 2020. Clinical characteristics of novel coronavirus cases in tertiary hospitals in Hubei Province. Chinese Medical Journal, 133 (9): 1025-1031.

[10] Tabari P., Amini M., Moghadami M., Moosavi M. 2020. International Public Health Responses to COVID-19 Outbreak: A Rapid Review. Iranian Journal of Medical Science, 45 (3): 157-169.

[11] T.C. Sağlık Bakanlığı Sağlık Hizmetleri Genel Müdürlüğü, Pandemi Hastaneleri. https://dosyamerkez.saglik.gov.tr/Eklenti/36907,pandemi-hastaneleripdf.pdf?0 (Erişim Tarihi: 16.06.2020).

[12] Chen S., Zhang Z., Yang J., Wang J., Zhai X., Bärnighausen T., Wang C. 2020. Fangcang Shelter Hospitals: A Novel Concept for Responding to Public Health Emergencies. The Lancet, 395 (10232): 1305-1314.

[13] TRT Haber, https://www.trthaber.com/haber/gundem/45-gun-icinde-turkiyeye-yeni-hastanelerkazandirildi-488828.html. (Erişim Tarihi: 16.06.2020). 
[14] Ecer B., Akdaş A., Kabak M., Dağdeviren M. 2020. Determining the Best Maternity Hospital by Using a Fuzzy Decision Making Model. International Journal of Computational and Experimental Science and Engineering, 6 (1): 7-12.

[15] Zulqarnain R.M., Abdal S., Ali B., Ali L., Dayan F., Ahamad M.I., Zafar Z. 2020. Selection of Medical Clinic for Disease Diagnosis by Using TOPSIS Method. International Journal of Pharmaceutical Sciences Review and Research, 61 (1): 22-27.

[16] Gündoğdu F., Kahraman C., Civan H.N. 2018. A novel hesitant fuzzy EDAS method and its application to hospital selection. Journal of Intelligent \& Fuzzy System, 35 (6): 6353-6365.

[17] Soltani A., Marandi E.Z. 2011. Hospital Site Selection Using Two-Stage Fuzzy Multi-Criteria Decision Making Process. Journal of Urban and Environmental Engineering, 5 (1): 32-43.

[18] Akdag H., Kalaycı T., Karagöz S., Zülfikar H., Giz D. 2014. The evaluation of hospital service quality by fuzzy MCDM. Applied Soft Computing, 23 (1): 239-248.

[19] Delavar M.R., Moradi M., Moshiri B. 2015. Earthquake Vulnerability Assessment For Hospital Buildings Using A Gis-Based Group Multi Criteria Decision Making Approach: A Case Study of Tehran, Iran. International Conference on Sensors \& Models in Remote Sensing \& Photogrammetry, Kish Island, Iran, 153-157.

[20] Büyüközkan G., Feyzioğlu O., Gocer F. 2016. Evaluation of hospital web services using intuitionistic fuzzy AHP and intuitionistic fuzzy VIKOR. IEEE International Conference on Industrial Engineering and Engineering Management, Bali, Indonesia, 607-611.

[21] Tyagi A., Singh P. 2019. Hospital performance management: A multi-criteria decision-making approach. International Journal of Healthcare Management, 12 (4): 286-291.

[22] Torkzad A., Beheshtinia M.A. 2019. Evaluating and prioritizing hospital service quality. International Journal of Health Care Quality Assurance, 32 (2): 332-346.

[23] Barrios M.O., Gül M., Meza P.L., Yücesan M., Jiménez E.N. 2020. Evaluation of hospital disaster preparedness by a multi-criteria decision making approach: The case of Turkish hospitals. International Journal of Disaster Risk Reduction, 49: 1-21.

[24] Halder B., Bandyopadhyay J., Banik P. 2020. Assessment of hospital sites' suitability by spatial information technologies using AHP and GIS-based multi-criteria approach of Rajpur-Sonarpur Municipality. Modeling Earth Systems and Environment, 6: 2581-2596.

[25] Saaty T.L. 1980. The Analytic Hierarchy Process. New York: McGraw- Hill.

[26] Saaty T.L. 2008. Decision making with the analytic hierarchy process. International Journal Services Sciences, 1 (1): 83-98.

[27] Velasquez M., Hester P.T. 2013. An Analysis of Multi-Criteria Decision Making Methods. International Journal of Operations Research, 10 (2): 56-66.

[28] Eren T., Özder E.H. 2016. Çok Ölçütlü Karar Verme Yöntemleri İle Bir İçecek Firması İçin Tedarikçi Seçimi. 4th International Symposium on Innovative Technologies in Engineering and Science, Alanya, Türkiye, 80-89.

[29] Özcan E., Ünlüsoy S., Eren T. 2017. A combined goal programming - AHP approach supported with TOPSIS for maintenance strategy selection in hydroelectric power plants. Renewable and Sustainable Energy Reviews, 78: 1410-1423.

[30] Özder E.H., Bedir N., Eren T. 2019. Yükseköğretimde Araştırmacı Seçiminde Çok Ölçütlü Karar Verme Yöntemlerinin Kullanılması: Bir İnceleme. Alanya Akademik Bakış, 3 (1): 19-33.

[31] Tezcan B., Eren T., Özcan E., Gür Ş. 2019. Bir Tekstil İşletmesinde Çok Ölçütlü Karar Verme Yöntemleri İle Personellerin Değerlendirilmesi. Trakya Üniversitesi İktisadi ve İdari Bilimler Fakültesi E-Dergi, 8 (2):1-20.

[32] Sarımehmet B., Hamurcu M., Eren T. 2020. Çok Kriterli Karar Verme: Kırıkkale YHT İstasyonu - Șehir Bağlantısının Sağlanması. Demiryolu Mühendisliği, 11: 26-40.

[33] Özcan E., Ökten S., Eren T. 2020. Decision making for promising quinoline-based anticancer agents through combined methodology. Journal of Biochemical and Molecular Toxicology, 34 (9):1-10.

[34] Ağaç G., Baki B. 2016. Sağglı Alanında Çok Kriterli Karar Verme Teknikleri Kullanımı: Literatür İncelemesi. Hacettepe Sağlik İdaresi Dergisi, 19 (3): 343-363.

[35] Liberatore M.J., Nydick R.L. 2008. The Analytic Hierarchy Process in Medical and Health Care Decision Making: A Literature Review. European Journal of Operational Research, 189 (1): 194207. 
[36] Rajak M., Shaw K. 2019. Evaluation and selection of mobile health (mHealth) applications using AHP and fuzzy TOPSIS. Technology in Society, 59: 1-17.

[37] Banar M., Özkan A., Kulac A. 2010. Choosing a recycling system using ANP and ELECTRE III techniques. Turkish J. Eng. Env. Sci., 34: 144-154.

[38] Ali J., Lee S., Roh B. 2019. Using the Analytical Network Process for Controller Placement in Software Defined Networks. MobiSys '19, Seoul, Korea, 545-546.

[39] Özcan E., Ünlüsoy S., Eren T. 2017. ANP ve TOPSIS Yöntemleriyle Türkiye'de Yenilenebilir Enerji Yatırım Alternatiflerinin Değerlendirilmesi. Selçuk Üniversitesi Mühendislik, Bilim ve Teknoloji Dergisi, 5 (2): 204-219.

[40] T.C. Cumhurbaşkanlığ 1 Strateji ve Bütçe Başkanlığı, 2020 Yılı Bütçesi Vatandaşın Bütçe Rehberi. http://www.sbb.gov.tr/wp-content/uploads/2020/01/2020_vatandasinbutcerehberi.pdf (Erişim Tarihi: 05.04.2020).

[41] T.C. Sağlık Bakanlığı Halk Sağlığı Genel Müdürlüğü, 2019-ncov Hastalığı Sağlık Çalışanları Rehberi (Bilim Kurulu Çalışmasi). https://hsgm.saglik.gov.tr/depo/haberler/ncov/2019nCov_Hastal_Salk_alanlar_Rehberi.pdf (Erişim Tarihi: 05.06.2020).

[42] T.C. Sağlık Bakanlığı Sağlık Hizmetleri Genel Müdürlügü̈, Sağlık Bölge Planlaması Hakkında Genelge ile Hastane Yatak ve Rolleri Tescil Onay1 2010/50. https://www.saglik.gov.tr/TR,11024/saglik-bolge-planlamasi-hakkinda-genelge-ile-hastaneyatak-ve-rolleri-tescil-onayi-201050.html (Erişim Tarihi: 12.11.2020).

[43] Sözcü Gazetesi, 25 hastanede 'coronavirüs'e karş1 özel oda oluşturuldu. https://www.sozcu.com.tr/2020/saglik/25-hastanede-coronaviruse-karsi-ozel-oda-olusturuldu5593353/ (Erişim Tarihi: 17.06.2020).

[44] Ömürbek N., Tunca M.Z. 2013. Analitik Hiyerarşi Süreci ve Analitik Ağ Süreci Yöntemlerinde Grup Kararı Verilmesi Aşamasına İlişkin Bir Örnek Uygulama. Süleyman Demirel Üniversitesi İktisadi ve İdari Bilimler Fakültesi Dergisi, 18 (3): 47-70.

[45] Koyuncu O., Özcan M. 2014. Personel Seçim Sürecinde Analitik Hiyerarşi Süreci ve TOPSIS Yöntemlerinin Karşılaştırılması: Otomotiv Sektöründe Bir Uygulama. H.Ü. İktisadi ve İdari Bilimler Fakültesi Dergisi, 32 (2): 195-218.

[46] Uludağ A.S., Doğan H. 2016. Çok Kriterli Karar Verme Yöntemlerinin Karşılaştırılmasına Odaklı Bir Hizmet Kalitesi Uygulaması. Çankırı Karatekin Üniversitesi İktisadi ve İdari Bilimler Fakültesi Dergisi, 6 (2): 17-47.

[47] Saaty T.L., William A. 2004. Super decisions software (Computer Software).

[48] Özdemir Y., Tüysüz S., Başlıgil H. 2016. Weighting The Risks For Nuclear Power Plants Using Ahp nnd Anp Methodologies. Sigma J Eng \& Nat Sci., 7 (2): 207-217. 